\title{
T. S. Eliot on Amal Donqul
}

Three Influences

By

Tahani Mohamed Said 


\section{Abstract}

This paper is intended to study the influence of T. S. Eliot $(1888-1965)$ on the Egyptian poet Amal Donqul (1940 - 1983), the researcher investigates three influences of T. S. Eliot on Amal Donqul's poetry: the first is that Amal benefited from Eliot's employment of prophetic visions in his poetry. The second is that Amal imitated Eliot in adopting his national heritage, the third is that the dramatic turn in Amal's poetry is an Eliotic turn. Three influences: prophesy, tradition and drama. Amal knew that the influence of Eliot's poetry was paramount on the world literary scene in general and in Arabic literature in particular. This anxiety of influence made Amal cautious about copying Eliot's experience; he tried his utmost to have his own voice, stemmed from Arabic history, and the Egyptian experience.

\section{Key words:}

Amal Donqul - T. S. Eliot - dramatic voice - tradition - prophecy - visions - influence

\footnotetext{
مستخلص

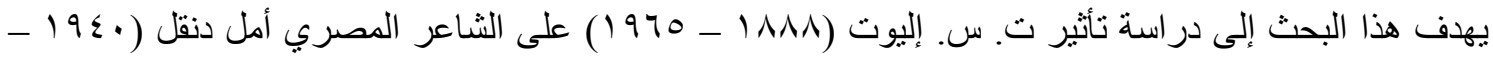

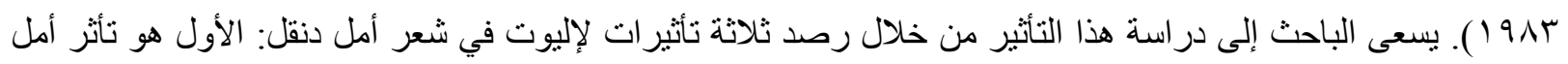
دنقل بتوظيف إليوت للرؤية التنبؤية في الثعر. و الثاني تأثثر إليوت على شعر أمل دنقل في توظيفه للتراث، حيث تأثر أمل

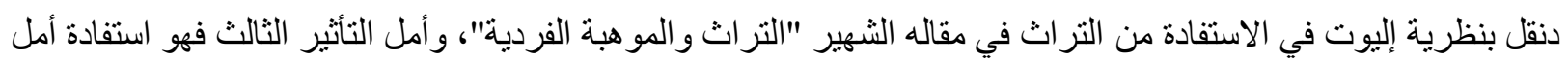
دنقل من منهج إليوت في توظيف الدراما في الشعر، حيث قام أمل دنقل بتوظيف العناصر الدرامية في قصائده، فجاءت قصائده حافلة بالصراع الدرامي والحوار بين الثخصيات المختلفة التي تمثل صوراً متباينة من صور التفاعل الاجتماعي فئي و السياسي. ومن المعروف أن تاثير إليوت على الثُعر اء العرب كان واضحًا في فترة الستينيات وما بعدها بعدما تمت ترجمة

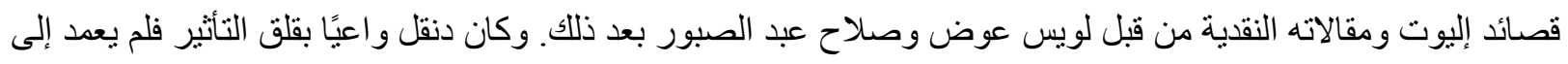
أن يكون نسخة طبق الأصل من إليوت، و إنما اجتهد ليكون لـه صوته الخاص به، وتجربته الخاصة في سياقه المختلف عن

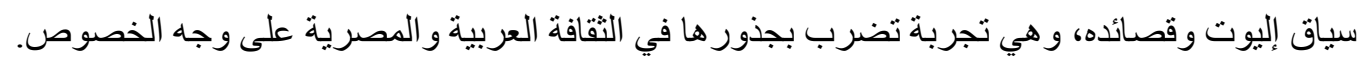
كلمات مفتاحية إليوت ـ أمل دنقل ـ التأثثر - الرؤية ـ النبوعة ـ التراث - شعر
} 


\section{T. S. Eliot on Amal Donqul}

\section{Three Influences}

The Influence of T. S. Eliot on Arabic poetry, especially after the translation of The Waste Land into Arabic in 1947 by the critic Louis Awad, was paramount. Before that Awad recommended, in "Al-Katib al-Misri" magazine (1946), Arab poets to leave the traditional end rhymed poetry, and advised them to follow T. S. Eliot and other experimental European poets. He has written this also in his introduction to his book of poetry entitled "Plutoland and Other Poems" (Cairo, 1947), in which he included poems having some characteristics of the English poems written by T.S Eliot at that time. Since then, the influence of T. S. Eliot became tangible, M. M. Badawi writes about Eliot's influence on Arab poets:

The influence of Eliot is shown not only in the structure and style, the use of myth and allusion and the interior monologue, in Iraqi, Lebanese and Egyptian poetry, but Eliot's attacks on the English Romantic poets, his reaction against what he regarded as their limitations both in style and subject matter, no doubt affected the attitude of the younger generation of Arab poets towards their own romantic poetry, making them reject the false simplicity, the sentimentality and sugary poeticality of some romantic poetry in favor of a pregnant style more capable of expressing reallife experience in all its complexity and harshness. (')

Eliot's influence on BadrShakiral-Sayyab, Nazek el-Mala'ka and Salah Abd al-Saburis well known. Amal Donqul was the youngest of them,"born in Upper Egypt, and like many writers known as the Generation of the Sixties, migrated to Cairo from the countryside. He came to be known as the vagabond poet". (`) Amal was aware of the wide influence of Eliot on the poets of his generation, and has done his best to get away from this influence without losing his independence. 
Amal succeeded inarticulating his own voice, however, he could not escape three Eliotic influences which remain obvious in his poetic achievement. The first influence is the prophetic vision which prevail Amal's poetry, the second is his use of tradition inspired by Eliot. The third is that dramatic element in his poetry which takes it away from pure lyricism to the horizons of dramatic expression.

\section{Prophetic visions:}

The relationship between poetry and prophecy is as old as Homer and Virgil. From the very beginning of poetry, prophecy was an essential element of its fabric. Poets claimed that they receive their creation from the muses. The muses were gods who were specialized in inspiration. For that reason Plato expelled poets from his Ideal Republic; because they imitate what is already imitated, and thus untrusted because they tell lies. The ancient Arabs thought that each poet had his own "jinn" from "WadiAbqar" (The Valley of Genius), his poetry is just a translation of what this Jinn inspires or communicates. That is why poetry is associated with prophecy, and poets are sometimes described as prophets. The legends of poets as prophets are everywhere in the works of poets like Homer, Virgil, and Milton. The Arab poet El-Mutannabi is said to haveclaimed to be a prophet, and had so many followers. Modern Arab poets incorporate legends of prophecy and future telling in their poetry. T. E. Eliot used clairvoyant characters in his poetry to point to the future of Europe in general and England in particular. Arab poets like Nazekal-Malai'ka, Salah Abd al-Sabour, BadrShakir al-Sayyab, and Amal Donqul used prophetic legends in their poetry to refer to future events. They were actually following a long tradition of prophetic poetry in the west and east. When T. S. Eliot's poems and critical works were translated and propagated in the Egypt, Egyptian poets began to follow the way he wrote poems. T. S. Eliot used the legend ofTiresias (among many legends), the blind prophet of Apollo who received visions and revealed the secrets of gods. 
There are corresponding prophetic motifs in the poetry of T.S. Eliot and the Egyptian poet Amal Donqul. Both poets used prophetic visions to transfer their messages. Eliot uses prophetic characters to personify the ailments of Europe after the first World War. Likewise, Donqul finds an equivalent of Tiresias in the Arab heritage; namely the legend of Zarqa' al-Yamamah which he could employ with dexterity and expertise. There are similarities between the use of this metaphor in both poets, which denote that the human experience is almost the same with each culture's idiosyncrasies and peculiarities. Donqul adopted Eliot's prophetic stance, with the difference that the Egyptian poet was more optimistic and enthusiastic. However, the prophetic vision of the two poets was virtual and practical. Eliot's visions came true when another world war broke out in 1939 in Europe, Amal's "Weeping Before Zarqaa' al-Yamamah" which he wrote in eve of the June 1967 defeat, and his "Don't Reconcile" (La Tusalih 1977) proved highly prophetic and far-sighted poems. The breaking out of The Second World War proved the authenticity of Eliot's prophetic visions. Amal Donqul's prophetic vision was authentic and powerful when he also prophesied the June 1967 defeat.Amal Donqul used the legend of Zarqa al-Yamamah (also among many legends), who had the ability to see things from a very long distance, Noh Radwan summarizes the legend:

According to classical Arabic legend, al-Zarqā' was a woman from the Arabian tribe of Jādīs who could see as far as the distance it would take travelers three days to cover. She warned her tribe of advancing trees when, in the distance, she saw the armies of another tribe travelling towards her own under their cover. ${ }^{(r)}$

One thinks that Amal Donqul had identified himself with the Zarqa alYamamahand other prophets in his poetry, as Eliot identified himself with Tiresias and other prophets in his poetry. Eliot writes in his notes to The Waste Land that the character of Tiresias is the most important character in the poem: 
Tiresias although a mere spectator and not indeed a "character" is yet the most important personage in the poem "uniting all the rest. Just as the one-eyed merchant, seller of currants, melts into the Phoenician Sailor and the latter is not wholly distinct from Ferdinand Prince of Naples, so all the women are one women, and the two sexes met in Tiresias. What Tiresias sees in fact is the substance of the poem. ${ }^{(\xi)}$

Here one thinks that Amal Donqul read the poetry of T. S. Eliot and internalized its motifs, especially oracular motifs in which the future is surveyed. Donqulincorporated the Arabian prophetic legends as Eliot incorporated the European ones. The stark examples in both poets being Eliot's The Waste Land, and Donqul's"Weeping before Zarqa' al-Yammmah" (1969). Donqul'sZarqa' corresponds with Eliot's Madame Sosostris in her inability to see the future, and her failure even to predict the near coming events in her life. Donqul's prophetic vision is clear in his poetry especially his 1976 poem entitled "La tusalih (Don't Make Peace) that's before President Anwar El sadat's visit to Israel.

The influence of T. S. Eliot on Arab poetry in general and the poets of the sixties in Egypt in particular is near paramount. Nazik Al-Mala'ika, BadrShakir al Sayyab, Adonis (Ali Ahmad Said), in addition to the poets of the sixties in Egypt (Salah Abdel Sabour, Ahmad A. Hegazy, and others who internalized Eliot's poetry and wrote in his mode especially in his use of tradition as a prophetic vehicle through which they endeavored to foresee the future catastrophes.

Amal wrote his "Weeping before Zarqa' al-Yammmah"on the eve of the June 1967 defeat, in which he predicted the June 67 Setback and its bad aftereffects on the Arab character's psychological stance. That diwan was actually his real beginning with true poetic creativity which brought him to the world of fame and distinction, as Eliot's "The Waste Land" was his real beginning with fame and distinction. Amal Donqul identified himself with Zarqa' al-Yamamah as Eliot identified himself with Tiresias sibyl and Madame Sosostris. Also we notice 


\section{Tahani Mohamed Said}

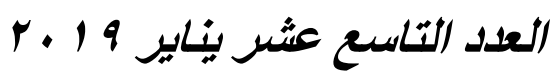

that both Eliot's and Donqul's poetry dealt with the same themes: trauma, disillusionment and death, themes of war and conflict. Both poets try to express man's inability to cope with life after the traumatic events in both contexts. There are more than one prophetic character in The Waste Land alone: Sibyl, Tiresias and the tarot reader (Madame Sosostris who is the closest one to Amal Donqul'sZarqa al-Yamamah.

There are similarities between Zarqa al-Yamamah and Madame Sosostris of the Waste Land. First is that both characters lost the ability to see and foressee. Donqul'sZarqa is no longer able to see through her blind eyes, the very complicated questions which the narrator asks remained unanswered to the end of the poem. The relationship between Madame Sosostris and the narrator is like the relationship between Donqul'sZarqa and his narrator. Although Madame Sosostris is a "famous clairvoyant", she could not expect just her "bad cold". Also her foreseeing abilities are limited:

Madame Sosostris, famous clairvoyante,

Had a bad cold, nevertheless

Is known to be the wisest woman in Europe,

With a wicked pack of cards. Here, said she,

Is your card, the drowned Phoenician Sailor,

(Those are pearls that were his eyes. Look!)

Here is Belladonna, the Lady of the Rocks,

The lady of situations.

Here is the man with three staves, and here the Wheel,

And here is the one-eyed merchant, and this card,

Which is blank, is something he carries on his back,

Which I am forbidden to see. I do not find

The Hanged Man. Fear death by water.

I see crowds of people, walking round in a ring.

Thank you. If you see dear Mrs. Equitone,

Tell her I bring the horoscope myself: 


\section{Tahani Mohamed Said}

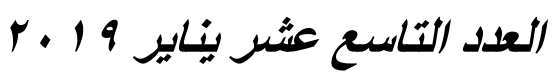

One must be so careful these days. ${ }^{(0)}$

What endangers Madame Sosostris's prophetic powers is her inability even to protect herself from "bad cold". Also her "pack of cards" are 'wicked'. She is forbidden to see the card which the one-eyed merchant carries on his back. She "cannot find the Hanged Man". And she even advises herself to "be careful these days"; which means that she cannot understand her tools and extract an agreed upon vision out of them. Similarly, Donqul'sZarqa is unable to see, the speaker drowns her with a flood of questions to which she does not offer a singlesatisfactory answer. He writes:

Speak out O sacred prophet

Speak out .. by God's sake .. by curse .. by the devil

Don't close your eyes, because rats ..

Lap my blood as their soup .. I cannot defend!

Speak up ... I am all disgraced

Night no longer hides my flaw .. nor walls!

Nor my hiding in the newspaper I read ..

Nor my seeking cover in the clouds of smoke! ${ }^{(\uparrow)}$

Madame Sosostris does not have the ability to read the tarot cards of her customer, although she was known as "the wisest woman in Europe", Zarqa, who is famous for her ability to see anybody advancing her oasis from a very long distances, is unable to see anything, and she leaves the narrator helpless and hopeless, begging her not close her eyes because "rats lap his blood as their soup, without being able to defend himself". The 'rats' here are reminiscent of Eliot's rats in line 115, part II entitled "A Game of Chess" in The Waste Land": I think we are in rats' alley/where the dead men lost their bones". Eliot's rats' alley suggests the trenches of the WWI, Amal Donqul borrowed the image to suggest also the trenches in Sinai desert in which our soldiers were hiding to catch the enemy before the enemy caught them in the June 1967 defeat. The narrator is 
supposedly Antara, the legendary pre-Islamic hero, explains the causes of the defeat:

They ordered me to "shut up .."

I shut up .. and pretended blindness ... headed eunuchs

I stayed with the slaves of Abs tribe shepherding flocks

Cutting their wool ..

Returning its camels

Sleeping in the barns of oblivion

My food: a scrap .. water .. and some dry dates.

Here I am in the hour of challenge !

When cavaliers .. and archers failed

Invite me to the battlefield !

I who has never tasted mutton ..

I who is the helpless

Who is moved away from my peers councils,

Invite me now to death .. not to counseling!! ${ }^{\left({ }^{\vee}\right)}$

Donqul's narrator is mentioning his miserable state with governors who do not take his opinion, and leave him a neglected sum, asking Zarqa to speak about the future consequences of this state. If Eliot's hero was invited to fight a war defending the interests of the new capitalists of Europe, Donqul's narrator is invited to fight a war defending Nasser's over-ambitious of Arab nationalism. The soldiers in both sides were sent to a battle which they did not know its real reasons, facing the death which foreseers could not predict. Zarqa is like Madame Sosostris held in a stagnant state:

Here are you Zarqa

Alone ... and blind!

And love songs are still ... and the lights

And the luxurious vehicles ... and the fashions ! 


\section{Tahani Mohamed Said}

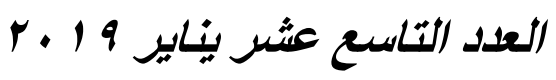

Where I could hide my disfigured face

In order not to disturb its purity .. ignorant ..distorted.

In men's and women's eyes!?

And you Zarqa ...

Alone and blind !

Alone and blind ! ${ }^{(\wedge)}$

The image of the seer used by both poets slip into their poetry like dye in clothes, with the difference that the Eliotic seer characters are pessimistic and helpless while Donqul's seer characters are hopeful and confidant. In Eliot's poems we have helpless characters inhabiting desolate and depopulated country haunted by the ghosts of the past. Most of the characters of both poets are suffering from loneliness and alienation, indecision and fear, inadequacy and inability, pessimism and distrust. This evident in Eliot's "The Waste Land", "Gerontion", "The Love Song of J. Alfred Prufrock", and in Donqul's "Weeping Before Zarqua' el-Yamama", "The Blind Soothsayer", "The Coming Testament", and other poems, characters who resist making decisions for fear of outcomes, continually worry that they will make a fool of themselves and that people will ridicule them.

\section{Use of tradition}

It is evident that Amal Donqul was influenced by T.S. Eliot in his theory oftradition, as explained in his essay "Tradition and the Individual Talent" (1919) in which he denounced Romanticism and valued classicism. Eliot was not a romantic poet, he saw Romanticism as an expression of loose emotion: he writes: "Poetry is not a turning loose of emotion, but an escape from emotion; it is not the expression of personality, but an escape from personality. But, of course, only those who have personality and emotions know what it means to want to escape from these things." ${ }^{(9)}$ Donqul was like Eliot in separating his personality from life. 


\section{Tahani Mohamed Said}

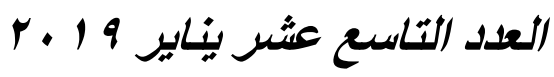

It is clear that Donqul's early poetry are personal and romantic; as they are areselfexpressions of his inner world, but they are dramatic poems in which there are have conflicting voices. Nonetheless, Amal Donqul was highly knowledgeable of Arabic tradition; as he was raised by a father who was a teacher ofArabic and wrote classical poetry.

Amal Donqul internalized Eliot's theory of tradition, Eliot writes in the function of criticism: "There is . . something outside the artist to which he owes allegiance, a devotion to which he must surrender and sacrifice himself in order to earn and to obtain his unique position. A common inheritance and a common cause unite artists consciously or unconsciously: it must be admitted that the union is mostly unconscious." ${ }^{(\cdot)}$ This is what Amal Donqul has done when he employed Arabic tradition in his poetry in a creative way. Abd al-Aziz alMaqalihwrites in his introduction to Amal'sComplete Poetical Works:

He used poetic inclusion in such a knowledgeable way that the included lines looked familiar with the structure of the poem, giving it the symbolic historical significance, not like what some poets of the new vogue did and are doing; what we can call "copy and paste", while their style remains flippant and discordant with the artistic and psychological context. (')

Al-Maqaleh also gives examples of Donqul's poetry in which he integratedtraditionto be part of his present, an example - of many examples from his poem entitled: "From Al-Mutanabbi's Memoirs in Egypt":

My maid asks me to hire guards for the house

Thieves have increased in Egypt .. without deterrence

I said: this is my incisive sword,

Put it behind the door ... a rampart

(What I need a raised sword for

Since I became Kafour'sneighbor?)

"O, Bairam days come back again as you desire

No matter you come as usual or my land made Jewish? 


\section{Tahani Mohamed Said}

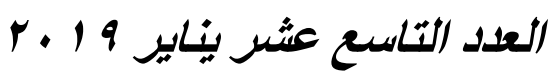

Egypt's vineyard keepers did not watch out) for the soldiers.

Odes fought instead,

I called: O Nile do waters flow blood

To overflow, and my kinsfolk wake if called?

"O, Bairam days come back again as you desire

No matter you come as usual". ('r)

The lines invite a number of associations, all of them become part of the present as they were part of the past. The figure of Al-Mutanabbiand his legendary relation to pride and self-esteem, his controversial relationship with governors, his courage and fearlessness. They also invite Egypt's wealth and how its governors regularly steal this wealth. Amal Donqul also invites the incessant struggle of the Arabs against the Roman empire in the past, in contrast with the present kind of struggle which our soldiers fight with odes and lemiricks instead of real weapons.

The lines and many other poems written by Amal Donqul embody his special use of the tradition. Inclusion does not look like inclusion; it slips into the fabric of the lines to become natural in its structure and symbolism,Muhsin J. alMusawi writes:

In Arabic, the past still holds significance, not only because itsurvives as language, and in accounts, symbols and values, but also because itacts through these on the present. Its registers may be recalled, invested,manipulated, and validated according to the rising occasion or need."Tradition," argues Anthony Giddens, "is not wholly static, because it hasto be reinvested by each new generation as it takes over its cultural inheritancefrom those preceding it". ('r)

Here,the Eliotic influence is evident; most inclusions in Amal's poetry perform their functions inside the text without being felt out of place or cacophonous. Donqul's poetry - like Eliot's - is based on allusions. Like Eliot when he could achieve a unity of the European cultural traditions, Donqul could 
achieve this cultural unity with Arabic and Islamic traditions. The Eliotic influence is evident in the titling of Amal's poems. Giving a look on the titles of Donqul's works reveals his obsession with the heritage: Weeping Before Zarqa' al-Yamamah (1969), The Book of Genesis, The Book of Exodus, The Coming Testament, New Documents about the Basous War, An Elegy on SakrQuraish, A Special Interview with Noah's Son, Psalms, The Last Words of Spartacus, Special Interview with Abu Mossa El-Ash'ary, From the Memoirs of El-Mutannabi, Paragraphs of the Book of the Dead, and The Murder of Koleib, and other poems. Most of Eliot's poem titles are taken from tradition: Journey Of The Magi, The Waste Land, Ash Wednesday, Gerontion, Old Deuteronomy, Sweeney among the Nightingales, and many other poems. Donqul was like Eliot in his belief of the deep reading in traditional literature, Eliot writes in "Religion and literature":

Wide Reading . . . is valuable because in the process of being affected by one powerful personality after another, we cease to be dominated by any one, or by any small number. The very different views of life, co-habiting in our minds, affect each other, and our own personality asserts itself and gives each a place in some arrangement peculiar to ourselves". ('६)

By this wide reading of traditional European literature, Eliot proved to be a nationalistic poet who wanted to unify the continent through literature. Amal also was a nationalistic poet who wanted to unify the Arabs, at least inside his mind. His poems were read pan-Arabian, a poetic unity he achieved more exciting than the political; simply because he expressed the Arab mind as Eliot was striving to express the mind of Europe. Like Eliot, Donqulsaw that tradition should be added to, and poetry should have its roots in the past. Eliot read extensively in the European tradition before he wrote poetry. Amal also read extensively in Arabic, Islamic as well as world tradition before he wrote poetry, his widowAbla alRoueni, wrote in her biography entitled: "El-Janoubi" The Southerner (1985): 
Amal read many books of tradition: epics and popular biographies, rereading them many times, in their different editions, moved a historical sense to unveil the layers accumulated behind the stories and information. ... To him, reading was a kind of investigation and discovery, it was not a mere accumulation of information, but what these information stir in the mind, we can say that his readings were creative works themselves. ... His interest in tradition and Arab and Islamic history was based on his continuous attempt to look for an identity - as he was always asserting - and on his sense of a strong belief that Egypt possessed an Arab spirit, and an Arab belonging. ${ }^{\left({ }^{10}\right)}$

We have another witness of Eliot's wide knowledge of European tradition, the witness of his Master in Harvard, Bertrand Russell saying: "My pupil Eliot was there, the only one who is civilized, and he is ultra-civilized, knows his classics very well, is familiar with all French literature from Villon to Vildrach, and is altogether impeccable in his taste but has no vigour or life-or enthusiasm". ${ }^{(17)}$ In Harvard Eliot received an intensive education in European and Christian tradition as Hazel Butz writes:

That Eliot recognizes Dante as the greatest religious poet, as well as the greatest influence upon his poetry, is significant; for Eliot's double recognition helps to subordinate the religious nature of his early work. Written is 1910 and 1911, Eliot's first important poem, "The Love Song of J. Alfred Prufrock", was introduced with an epigraph from Dante's Inferno. Eliot's poem, like Dante's, is really the beginning of a spiritual pilgrimage, in literature, from despair to beatific vision, a pilgrimage which Eliot redefines for the contemporary world. ${ }^{(' v)}$

Amal Donqul was - like Eliot - an informed reader of tradition, having a strong belief in its mutability. Eliot could apply his theory of tradition in his poetry and poetic drama.Eliot thought that a poet should enjoy this historical sense of the past, another idea in his theory of tradition explained in seminal essay: Tradition and Individual Talent, its quotation may shed light on his influence on Donqul. Eliot writes:

A perception, not only of the pastness of the past, but of its presence. . . This historical sense, which is a sense of the timeless as well as the temporal and of the timeless 
and of the temporal together, is what makes a writer traditional. And it is at the same time what makes a writer acutely conscious of his place in time, of his own contemporaneity. ${ }^{\left({ }^{\prime}\right)}$

Amal Donqul was a modernist, he learnt this modernism from Eliot. But Amal's modernism was different, Amal could adapt western modernism for the sake of creating an Arab modernism, an original modernism which devoid of ambiguities and complexities. Amal Donqul's popularity in the Arab World is due to his relative explicitness, as well as to the fact that he could achieve a unity of culture fabricated from his allusions to the past, a unity of the pre-Islamic, Islamic and Christian tradition. Within this cultural unity he also could voice the deep concerns of the Arabs everywhere, their political, social and even cultural causes as well as their deep wounds as in this poem in which he equals Sinai with "Qatr El-Nada" in his poem entitled: "Mourning Suits Qatr al-Nada":

Chorus:

Qatr El-Nada ... O Uncle.

A Horse without a horseman

Qatr el-Nada ... O eye

Princess of the two sides

A voice

Khomarawyh was lying on the lake of mercury

And the female singers and Heavenly daughters

Troding on musk and Cavour,

The poor and the dervishes in front of his closed palace..

Waiting for the scattered gold..

Waiting for a small armful of light. ${ }^{(19)}$

The story of Qatr al-Nada is narrated in Cambridge History of Egypt: 


\section{Tahani Mohamed Said}

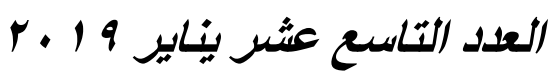

In 272/892, the Caliph al-Mu'tadid married Qatr al-Nada, "Dew Drop", Khmarawayh's daughter. He provided her with a dower of 1,000,000 dinars, a wedding guest that was considered the most sumptuous in Medieval Arab history. ... The luxury and dissipation indulged in by Khumarawayh ultimately overwhelmed him, and he was assassinated in Damascus in Dhu'l-Qa'da 282/January/ February 896 by his court eunuchs, who had taken advantage of his absence to satisfy the insatiable sexual appetites of his harem women. He left an empty treasury, the dinar having lost a third of its value as a result of his excessive prodigality. He had lived in luxury, and was rumored never to have mounted the same horse twice. $^{(r \cdot)}$

Summoning the legendary tale of Qatr el-Nada' to stand for the occupied Sinai is inspired by Eliot's summoning of Philomela and her "change by the barbarous king" in The Waste Land":

Above the antique mantel was displayed

As though a window gave upon the sylvan scene

The change of Philomel, by the barbarous king

So rudely forced; yet there the nightingale

Filled all the desert with inviolable voice

And still she cried, and still the world pursues,

"Jug Jug" to dirty ears. (r)

The story is narrated by Ovid in Book VI of "Metamorphoses": The beautiful Philomela is kidnapped, raped, and imprisoned by her sister Procne's husband, King Tereus. To prevent Philomela from revealing what he has done, Tereus then cuts out her tongue. Imprisoned, isolated, and unable to speak, Philomela weaves a tapestry depicting her suffering at Tereus' hands and sends it to Procne. Procne, enraged, frees her sister. The sisters then take their revenge on Tereus, murdering his and Procne's son and feeding the boy's body to the king. When the sisters reveal what they've done, Tereus charges them in fury. Before he can reach them, however, all three are transformed into birds. ${ }^{(}{ }^{(1)}$ 


\section{Tahani Mohamed Said}

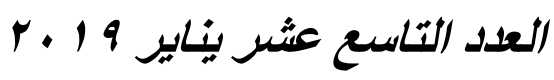

The recalling of Qatr al-Nada which is inspired by Ovid and Eliot to refer to the occupation of Sinai by Israel after the June 1967 defeat, invites a series of associations. Suppression of speech, the silencing of women, and the inability of the governors to rescue the homeland. Amal Donqul asks at the end of the poem: Khomarawyh was lying on the lake of mercury

In his evening nap.

Who, by God, will rescue the imprisoned princess?

Who, by God, will rescue her?

By sword, or by hoax $?^{\left({ }^{(r)}\right.}$

Here, the historical sense of the past extends to the present, the past, the present and the future become one unit. This is how Eliot's thoery of traditon is realized by Amal Donqul. The feeling that the whole of Arabic literature from pre-Islamic to the present has an immediate existence in the present. In this respect Eliot's influence on Donqul is obvious, Eliot writes:

The historical sense involves a perception, not only of the pastness of the past, but of its presence; the historical sense compels a man to write not merely with his own generation in his bones, butwith a feeling that the whole of the literature of Europe from Homer and within it the whole of the literature of his own country has a simultaneous existence and composes a simultaneous order. ${ }^{(r)}$

Tradition in the mind of the Arab poets is not limited to Arabic poetry or Islamic literature in general, but "in Arabic poetics tradition is even more inclusive, as modern consciousnessstretches it beyond the Islamic period to embrace the legacies of theSumerians, Babylonians, Phoenicians, and ancient Egyptians". ${ }^{(\longleftarrow)}$ However, present should not be a submissive imitation of longgone prototypes. Tradition should the mirror through which we can see ourselves. We have to differentiate between reading tradition and reviving it in ourselves. This idea reminds of Amal Donqul's treatment of Christian Tradition of the Old 
Testament in his poem entitled "The Coming Testament" which came as an embodiment of this "presence of the past in the present":

Chapter III

I said:

Let love be on earth, and it was not

I said:

Let river dissolve into ocean

Ocean into drought

Drought into fertility

Sprouting bread to sustain hungry hearts

Grass for the earth's cattle

Shade for exiles in sorrow's desert

I saw the son of Adam

Raising his fences around God's personal farm

Shopping for border guards

Selling bread and water to his brethren

Milking lean cows

I said:

Let love be on earth, and it was not

Love was now possessed

By those who could afford the price

And God saw this was not good. ${ }^{\left({ }^{\circ}\right)}$

Love, drought, hungry hearts, son of Adam, lean cows, God's dissatisfaction, all these images carry out the idea of the bareness of the life of the narrator. They are not distant from the images of The Waste Land in which Eliot's narrator refers to "a heap of broken images" which the son of man knows, the scarcity of love on earth as personified in "A Game Chess", the lean cows of Egypt and how prophet Joseph treated the crisis. 
In another poem entitled "Paragraphs from the Book of the Dead" we read in the first line what reminds us of line (8) of The Waste Land in which Eliot writes: "Summer surprised us,coming over the Starnbergersee,.." Donqul writes:

Autumn surprised me in Nissan

And the quails..

Perched on the shores of northern sea

I asked for what myself loves... before sleep

I did not find .. except the torture of fasting

I asked for what myself loves ..

(In Shadow and the sun)

I did not find myself !!

Here I am behind the glassy windows

Watching by the fading sun setting:

My absent bird ! ${ }^{(r \uparrow)}$

Although the narrator is reminding the reader of a paragraph from The Egyptian Book of the Dead, the voice of the narrator of The Waste Land haunts him. In his saying "Autumn surprised me in Nissan", is reminiscent of Eliot's "April is the cruelest month"; as Nissan according to the Assyrian calendar corresponds with April according to the Georgian calendar. The narrator who 'does not find himself' is reminiscent of the aristocratwoman in the opening of "The Burial of the Dead" who claims to be a German Russian, belonging to recently defeated empires. Donqul wrote his poem in 1969 after a bitter defeat in June 1967. This historical sense of the tradition which made the dead contemporary is what Eliot himself achieved in The Waste Land under the title of A Game of Chess: when he writes:

The Chair she sat in, like a burnished throne,

Glowed on the marble, where the glass

Held up by standards wrought with fruited vines 
From which a golden Cupidon peeped out

(Another hid his eyes behind his wing)

Doubled the flames of sevenbranched candelabra

Reflecting light upon the table as

The glitter of her jewels rose to meet it,

From satin cases poured in rich profusion;

In vials of ivory and coloured glass

Unstoppered, lurked her strange synthetic perfumes,

Unguent, powdered, or liquid - troubled, confused

And drowned the sense in odours; stirred by the air

That freshened from the window, these ascended 90

In fattening the prolonged candle-flames,

Flung their smoke into the laquearia,

Stirring the pattern on the coffered ceiling.

Huge sea-wood fed with copper

Burned green and orange, framed by the coloured stone,

In which sad light a carvèd dolphin swam.

Above the antique mantel was displayed

As though a window gave upon the sylvan scene

The change of Philomel, by the barbarous king

So rudely forced; yet there the nightingale

Filled all the desert with inviolable voice

And still she cried, and still the world pursues,

"Jug Jug" to dirty ears. ( ${ }^{\mathrm{r}}$ )

Burnished thrones, marble, fruited vines, golden Cupidon, jewels, perfumes, coffered ceilings/the change of Philomela by the barbarous king, the weeping nightingale which filled the desert with his voice. We have two contrasting scenes in spite of the scene of luxury, we have the scene of death. We have the unfulfilled love of Cleopatra to Anthony, we suicide of Cleopatra and Anthony, we have the defeat of the Egypt by Octavius Caesar, all these traditional images became current by Amal Donqul's dexterous use of them. The character of 
Cleopatra, a tradition, is absorbed in the Shakespeare's and Eliot's texts, as the characters of the "Book of Genesis" are absorbed in "The Coming Testament" by Amal Donqul who learned this method from his early master: T. S. Eliot in his book "Tradition and the Individual Talent", he writes:

Yet if the only form of tradition, of handing down, consisted in following the ways of the immediate generation before us in a blind or timid adherence to its successes, "tradition" should positively be discouraged. ... It involves, in the first place, the historical sense, which we may call nearly indispensable to anyone who would continue to be a poet beyond his twenty-fifth year; and the historical sense involves a perception, not only of the pastness of the past, but of its presence; the historical sense compels a man to write not merely with his own generation in his bones. ${ }^{(\uparrow \wedge)}$

Amal Donqul did not practice criticism, but he benefited from critics, Eliot's criticism has had its obvious influence on him, this we can deduce from his poetry not from his confessions. Poets sometimes consider some critical theories so universal and common to be a natural possession. He must have read and absorbed "Tradition and the Individual Talent" very well, applied its admonitions in most of his poetry, understand the precious lesson that:

No poet, no artist of any art, has his complete meaning alone. His significance, his appreciation is the appreciation of his relation to the dead poets and artists. You cannot value him alone; you must set him, for contrast and comparison, among the dead. I mean this as a principle of æsthetic, not merely historical, criticism. The necessity that he shall conform, that he shall cohere, is not one-sided; what happens when a new work of art is created is something that happens simultaneously to all the works of art which preceded it. The existing monuments form an ideal order among themselves, which is modified by the introduction of the new (the really new) work of art among them. The existing order is complete before the new work arrives; for order to persist after the supervention of novelty, the whole existing order must be, if ever so slightly, altered; 


\section{Tahani Mohamed Said}

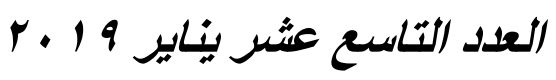

and so the relations, proportions, values of each work of art toward the whole are readjusted; and this is conformity between the old and the new. ${ }^{\left(r^{q}\right)}$

Amal Donqul imitated Eliot in viewing culture, Eliot viewed European culture as coming from Christian Graeco-Roman roots, a one cultural unit; the unity between these three elements: Christianity, Roman and Greek civilizations as one whole leading to understanding the present as well. Amal viewed Arabic culture being consisting of pre-Islamic, Islamic and Christian as one whole leading to understanding the present as well. There is not novelty without tradition, and no tradition without novelty. The past and the present go together. This what Eliot has done in The Waste Land" in the part entitled "Unreal City": Unreal City,

Under the brown fog of a winter dawn,

A crowd flowed over London Bridge, so many,

I had not thought death had undone so many.

Sighs, short and infrequent, were exhaled,

And each man fixed his eyes before his feet.

Flowed up the hill and down King William Street,

To where Saint Mary Woolnoth kept the hours

With a dead sound on the final stroke of nine.

There I saw one I knew, and stopped him, crying: "Stetson!

"You who were with me in the ships at Mylae!

"That corpse you planted last year in your garden,

"Has it begun to sprout? Will it bloom this year?

"Or has the sudden frost disturbed its bed?

"Oh keep the Dog far hence, that's friend to men,

"Or with his nails he'll dig it up again!

"You! hypocrite lecteur! —monsemblable, —mon frère! $!^{(r \cdot)}$

The character of Eliot's Tiresias is dispersed in Donqul's works especially reaching its full revelation in "Weeping Before Zarqa' al-Yamamah". The purpose 
of Donqul's use of the tradition is to put the past in front of the present as Eliot did. Tiresias as Zarqa' became a poetic figure burdened with significances that transcend its essential references. The most common and important significance the fact that both blind figures in the poetry of the two poets embody the characters' inability to cope with the present life of their environments, with the difference that we have some hope in the poetry of Amal Donqul and hopelessness in the poetry of T. S. Eliot. The difference lies in the fact that Eliot's poetry is pessimistic, while Donqul's is not; rather it is a resistance poetry, that can easily be classified with the poetry of Seamus Heaney, W. B. Yeats, Mahmoud Darwish and others. In his introduction to the Amal'sDiwan the poet Abdel Aziz el-Maqaleh writes about Amal's ability to change the 1967 setback into resistance in contrast with other poets who became pessimistic after the 1967 defeat, writing long elegiac poems. AmalDoqul was different:

He changed the 1967 setback literature to be a literature of resistance, a resistance of the mistakes of the Egyptian way of life, of the western aggression on us a literature of challenge not surrender and helpless crying on the spelt milk in the summer of misfortune and failure. $^{(r)}$

\section{The dramatic turn:}

Amal Donqul did not write plays, his poverty and bad health did not help him to write plays. However, the majority of Amal's poems are dramatic; he has a natural liking for dialogue, the dramatic and conflict. He seems to have a love for drama and the dramatic form. He seems also to have a passion for the living speech of the ordinary people. If he was not a playwright, he was a dramatic poet of the first rank. His poetry possesses the quality which makes it suitable to be read on the stage, besides being written in the conversational language. Amal's poetry is based on conflict and explicit dialogue and monologue. There are voices clashing internally in his characters. Most of the poets of the sixties in Egypt were 


\section{Tahani Mohamed Said}

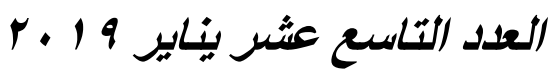

specially dramatic. Amal Donqul was known as the pauper-poet, the vagabond poet, moving in the cheap hotels of Cairo, sharing friends their little money and food. His poetry came as the poetry of experience which cannot be built except on dramatic strategies. Amal usually creates a dramatic situation with audience in the poem. He also creates a relationship between speaker, the listener and the readers. Amal could benefit from Eliot's dramatic technique in his poetry to get away from the pure lyricism of the Romantics.Ezz el-Din Ismael writes:

It is not easy to realize this dramatic character in a work of poetry without these essential elements necessary for drama: man, conflict facing contradictions of life. Man sometimes quarrels with himself in every experience, or with others. In either case, he can produce a piece of dramatic art, or establish a philosophical structure to explain. $^{(r r)}$

Like Eliot's poems, Amal Donqul's are loaded with dramatic situations based on conflict and people facing the dilemmas of life. Amal also inherited Eliot's hostile situation towards Romanticism and its failed lyricism. Even in summoning tradition, Amal was inspired by Eliot in summoning dramatic characters of tradition, to voice contemporary issues. He benefited from Eliot his use of dialogues, and sometimes monologues in his poems, witness this poem in which he summons a western tradition, the Spartacus episode in "From the Last Words of Spartacus":

Hanged I am on the Morning gallows, My forehead - with death - bowed

Because I did not bow it .. alive

O my brothers who cross the square bowed and silent

Drifting by the end of the evening

In the street of Al-Askander el-Akbar:

Don't be shy ... raise your eyes up to me

Because you are hanged beside me ... on Caesar's gallows.

Do raise your eyes up to me

Perhaps .. when your eyes meet with death in mine

Mortality may smile in me ..

Because you raised your heads once. ${ }^{(r \varepsilon)}$ 
In this poem we notice the conversational tone of the lines, the voice of the narrator is mixed with other voices which come from inside the self, running the internal monologue and the whole conflict. A hanged Spartacus is talking from death to a fellow mortal reminding him of his past struggle against slavery. Then he talks to many people whom he calls "brothers" crossing a square bowed and silent towards Alexander the Great street, and advises them not to bow their foreheads". This summary is confusing of course; because the poem plays on the symbolic and the magical. The people who are "drifting by the end of the evening, in the streets of Alexander the Great" are reminiscent of the Waste Land's "I see crowds of people, walking round in a ring", and in a "crowd flowed over London Bridge, so many/I had not thought death had undone so many". The dramatic element in the poem does not come only from the conversation between the characters, or the internal monologue which takes place inside the narrator's self, it comes also from this implicit conversation run between the author and the other author, between Donqul and Eliot, or between texts, a conversation which extends to the reader as well.

The dramatic turn in the poetry of Amal Donqul is evident from the titles of his poems: The Last Words of Spartacus, Weeping Before Zarqa al-Yamamah, Diaries of a Middle Aged Young Man, The Last Supper, A special Conversation with Abu-Mosa al-Asha'ray, Death on Bed, Paragraphs from the Book of the Dead, From the Papers of Abu-Nawwas, A Special Interview with Noah's Son, The Coming Statement, and many other poems. These poems recallEliot's dramatic structure on conversation with internal and external characters as well as dramatic monologues in which the situations are internal. We can understand Donqul's self through the voices uttering his poems. In this respect, the influence of Eliot's "The Love Song of J. Alfred Prufrock" is obvious. In this poem the experience of the speaker relies in his consciousness. The other thing is that this experience is told in the first person; the most suitable mode for expressing 
experience. The conflict takes place inside the character's self; in spite of the many voices that appear in the poem and carry out the conversation. Amal Donqul followed this Eliotic mode especially in this poem entitled: "A Special Interview with Noah's Son", in which he writes:

Noah's flood is coming nearer.

Here are the cowards fleeing to the ship

While I was...

The city's youth were

Bridling the unruly horse of the water

Carrying water on both shoulders.

And racing time

They were building stone dams for themselves

Hoping to save the bosom of youth and civilization

Hoping to save... the homeland!

...the master of the Ark shouted at me-before the advent

Of quietude:

"Escape from a country...where the spirit is no longer"!

I said:

Blessed are those who ate its bread...

In days of prosperity

And turned their back on it

In times of adversity!

Glory to us, we who have stood

God has obliterated our names!

to defy destruction...

And seek refuge in a mountain that doesn't die

They call it 'the people!'

We refuse to flee...

And we refuse to wander!

My heart, knit with injuries

Cursed by commentaries

Is resting, now, on the city's remains

A blossom bland

Still...

After it said "No" to the ship...

and loved the homeland. ${ }^{(*)}$

The conflict in the poem is very much like the conflict in "The Love Son of J. Alfred Prufrock" in that the speaker is the mirror through which the poet writes 


\section{Tahani Mohamed Said}

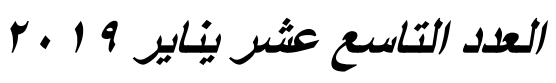

about his psychological experience. However, Donqul steps further when he makes the poem an expression of his own experience as an expression of the crisis of his homeland. That "A Special Interview with Noah's Son" is an expression of the crisis of the poet's country, it is also a personal one as his widow Abla elRoueni tells us:

The idea of travelling abroad seemed the economic solution for a man seeking marriage. Thus the idea of marriage started with a psychological problem taking him from the state of a poet interested mainly in poetry to a mere young man interested in issues related to marriage and how it should be achieved by preparing an apartment and the other marriage material facilities. Beirut was the only way especially when Talal Suleiman, editor of Elsefeer newspaper offered him the responsibility of the cultural department. For me I found this beginning destructive of my relation with him, turning the relation from a girl who could grant him some quietude and reassurance to his restless self, to a wife willing to send him to exile to once more. And in 1976 Amal wrote his poem "A Special Interview with Noah's Son" which he give me saying that it is the first poem he writes for me. The poem bore a political and social vision in the first place, and I was not there at all, I wondered. He answered:

- $\quad$ No, you are the core of it, you could return my beautiful sense of the homeland .. its last lines are especially written for you:

My heart, knit with injuries

Cursed by commentaries

Is resting, now, on the city's remains

A blossom bland

Still...

After it said "No" to the ship...

and loved the homeland. ${ }^{(r)}$

Unlike Eliot's dramatic mode in his poetry, in locating the experience in the very depths of the psyche, Amal Donqul carries his experiences out to the exterior as well as the interior. His poems are but incessant dialogues between his characters and his selves. Eliot believed strongly that poetry should be dramatic, and that the dramatic element should be found in all great poetry. He believed in 


\section{Tahani Mohamed Said}

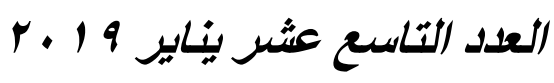

the integral unity between drama and poetry, one cannot do without the other. He believed in the necessity of drama for poetry; and that two should united to create an artistic whole. He once asked in his essay entitled "Dialogue on Dramatic Poetry":

What great poetry is not dramatic? Even the minor writers of the Greek Anthology, even Martial, are dramatic. Who is more dramatic than Homer or Dante? We are human beings, and in what are we more interested than in human action and human attitudes? Even when he assaults, and with supreme mastery, the divine mystery, does not Dante engage us in the question of the human attitude towards this mystery--which is dramatic ${ }^{\left({ }^{\top}\right)}$

So, Amal Donqul inherited this theory of the complete unity between the poetic and the dramatic. Donqul did explain his theory in prose as Eliot did; he considered himself a sincere disciple of his forerunner; that he went directly to application. There is a real fusion of drama and poetry in most of the poems of Amal Donqul. Eliot applied his theory on his poetic plays, Donqul applied on his poems. There are characters and conflict among characters. There are intense dramatic situations capable of expressing the deepest emotions.Donqul has done this especially in poems like "The Coming Testament", "Commentary on What Happened", and "New Sayings on the Basous War". His poems entitled "Papers of Room 8" written in the hospital, written in a tranquil smooth dramatic mode reminiscent of the atmosphere of Eliot's famous play "Murder in the Cathedral". Donqul benefited from Eliot's use of the chorus in his poems to enhance the dramatic structure, and align himself with the great dramatic poets. 


\section{Conclusion}

After translating The Waste Land in 1947, Louis Awad, a graduate of Cambridge and Preston, called Egyptian poets to give writing Arabic poetry in the traditional way. He called them to destroy "Amoud el-She'r" (end rhymed poetry), and began a new stage in which they should write free poetry, free from the bonds of rhyme and the restraints of regular meter. Awad also invited the Egyptian poets to imitate T. S. Eliot in writing poetry especially in his poem entitled "The Waste Land". Not after many years Eliot's figure became looming very strongly on the poetic scene of the sixties, especially after the poet and poetic playwright Salah Abdel Sabour translated, published and commented on some of the Eliot's achievements in poetry, drama and criticism. Eliot practiced his influence on the first generation of the poets of free verse. His influence was evident on Nazek elMala'kah, Badr Shaker el-Sayyab, and Ahmad Abdel Mo'tyHegazy. Amal Donqul belonged to the poets of the sixties. His father was a poet and an government official in Quena south of Egypt. Amal received a traditional education and became well versed in traditional books and poetry.

Amal Donqul tried his best to have his own poetic voice. His vagabond live helped him to be independent of all authorities, even the authority of texts. He must have read T. S. Eliot extensively, and tried internalized him. In this paper we try to put hour hand on three influences of Eliot on the poetry of Amal Donqul. He must have been influenced by Eliot's prophetic visions and the use of prophetic voices in poetry. Amal Donqul also must have been influenced by Elio's ability to use tradition. Eliot wrote a theory on tradition and the individual talent. No doubt that Amal Donqul has benefited from this theory.

The paper discusses three Eliotic influences on the poetry of Amal Donqul. First that Donqul was affected by Eliot's use of prophetic visions, this evident in most of the poems of Amal Donqul. The second influence is Eliot theory of 
tradition from which Amal Donqul has been benefited and employed in his poems. The third influence is Eliot's dramatic mode which Donqul has adopted in his poems. Donqul did not separate his human experience from his literary creation, as we have just seen in his poem "A Special Interview with the Son of Naoh". 


\section{Works Cited}

(1) M. M. Badawi, A Critical Introduction to Modern Arabic Poetry (London: Cambridge University Press, 1975), p 226.

( ) Ferial J. Ghazoul, Genesis and Exodus in the Poetry of AmalDonqul" (Arab World Books.com

https://www.arabworldbooks.com/readers2011/articles/dunqul_exodus_genesis_ghazoul.htm

${ }^{(ॅ)}$ NohaRadwan, AmalDunqul, The Prince of Protest Poets (Journal of Arabic Literature, Vol. No. 2/3 45, URL, Jstor, 2014), p: 220.

${ }^{(\varepsilon)}$ Eliot's Notes on the Waste Land.

${ }^{\left({ }^{\circ}\right)}$ Lawrence Rainy (ed.) The Annotated Waste Land with Eliot's Contemporary Prose (Yale University Press, $2^{\text {nd }}$ ed. 2006), pp, $58-59$.

${ }^{(\urcorner)}$Abd al-Aziz al-Maqalih (ed.) AmalDonqul, Al-A'mal al-Shi'riyya al - kamila (Cairo, MaktabatMadbouly 1987), p: 122. My Translation.

${ }^{(\vee)}$ Ibid. pp, 123 - 124. My translation.

${ }^{(\wedge)}$ Ibid, p; 126. My translation.

${ }^{(9)}$ Frank Kermode (ed.), T. S. Eliot, "Tradition and the Individual Talent", Selected Prose of T.

S. Eliot (New York: Harcourt Brace \& Co., 1975), p: 43.

('.) T. S. Eliot, Tradition and the Individual Talent. Selected Essays, London: Faber and Faber, 1932), p: 14.

(') $\mathrm{Abd}$ - al - Aziz al - Maqalih, Op.cit, p 15. My translation.

('r) Ibid., p: 16. My translation.

${ }^{\left({ }^{\top}\right)}$ Mhusin J. al-Musawi, Arabic Poetry: Trajectories of Modernity and Tradition (Rutledge, 2006), p: 4.

(१६) T. S. Eliot, Points of View (Hyperion Press, 1980), p: 1^.

('0) Abla al-Roueni, Al-Janoubi (The Southerner), A Biography of AmalDonqul (Sou'ad ElSabbah Printing Press, $1^{\text {st }}$ impression, 1992), pp: 80 - 81. My translation

(') Quoted in: Garrick Davis, "What Make of T. S. Eliot" (US Government Printing Office, Provided by Proquest LLC. Humanities, V. 37, 4, 216) $14+$

${ }^{\left({ }^{\prime}\right)}$ Hazel E. Butz "The Relation of T. S. Eliot to the Christian Tradition" unpub. Diss. Indiana University, 1953), p: 14.

(^^) Tradition and the individual Talent, Op.cit, p: 14.

${ }^{(19)}$ Abd al-Aziz al-Maqalih, Op.cit. p: 202. My translation 
${ }^{(r \cdot)}$ M. W. Daly and F. Petry (ed.) The Cambridge History of Egypt, V. 1 , Islamic Egypt 640 1517 (Cambridge University Press, 1998), p: 1067.

(r) The Waste Land, Op. cit.

${ }^{(r)}$ https://wasteland.windingway.org/99/the-change-of-philomel.

(r) Al-Maqaleh, Op. cit, p: 203. My translation

${ }^{\left({ }^{(r)}\right.}$ T. S. Eliot, Selected Essay, op.cit., p: 4.

${ }^{\left({ }^{\natural}\right)}$ Muhsin J. al-Musawi, Arabic Poetry: Trajectories of Modernity and Tradition (Rutledge, 2006), p: 14.

${ }^{\left({ }^{(\circ)}\right.}$ Ferial Ghazoulhttp://www.arabworldbooks.com/readers2011/articles/dunqul_exodus_genesis.htm

(ฯ) Al-Maqaleh, Op. cit, pp: 199 - 200. My translation

${ }^{\left({ }^{r}\right)}$ The Waste Land, Op. cit.

${ }^{\left({ }^{\wedge}\right)}$ T. S. Eliot, Selected Essay, op.cit., p: 14.

${ }^{\left({ }^{(9)}\right.}$ T. S. Eliot, Selected Essay, op.cit., pp: $14-15$.

${ }^{(r \cdot)}$ The Waste Land, Op. cit.

(r)Al-Maqaleh, Op. cit, p.12. My translation

${ }^{(\top)}$ Ezz al - Din Ismael, Contemporary Arabic Poetry: Its Causes, Artistic and Moral Phenomena (Dar El-Fikr el-Araby ( $3^{\text {rd }}$ edition, 1966), p: 284. My translation.

${ }^{(\longleftarrow \varepsilon)} \mathrm{Al}$ - Maqaleh, Op. cit.pp: 110 - 111. My translation.

${ }^{\left({ }^{\circ}\right)}$ The poem is translated by Gaelle Raphael in: https://arablit.org/2011/07/20/egypts-prince-ofrefuseniks-the-poetry-of-amal-dunqul/

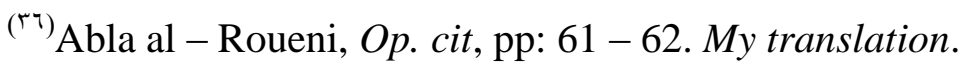

${ }^{\left({ }^{v}\right)}$ Quoted in F. O Matheiessen, The Achievement of T. S. Eliot: An Essay on the Nature of Poetry (New York: Oxford University Press, $2^{\text {nd }}$ ed. 1947), p: 47. 